\title{
Islamic Undergraduate Students' Perceptions toward Teacher's Basic Pedagogical Competences at English Tutorial Class
}

\author{
Choiril Anwar ${ }^{1}$, Hartono $^{2}$, Abdurahman Faridi ${ }^{3}$, Issy Yuliasri ${ }^{4}$, Hendi Pratama ${ }^{5}$ \\ English Language Education Study Program, Universitas Islam Sultan Agung, \\ J1. Kaligawe Raya Km. 4 Semarang, Indonesia ${ }^{1,2}$ \\ Doctoral Program, Universitas Negeri Semarang, \\ Kelud Utara III Petompon Gajahmungkur Semarang, Indonesia ${ }^{1,2,3,4,5}$ \\ \{choirilanwar@unissula.ac.id ${ }^{1}$, hartono@unissula.ac.id², pakdur@mail.unnes.ac.id ${ }^{3}$, \\ issy.yuliasri@mail.unnes.ac.id ${ }^{4}$, hendipratama@mail.unnes.ac.id ${ }^{5}$ \}
}

\begin{abstract}
A teacher's professional development is something really significant for any institution, including a private international language center in an Islamic university. This study was aimed at investigating students' perceptions toward teachers' professional development particularly dealing with their basic pedagogical competences such as asking question, giving feedback, making variation, explaining, opening and closing the lesson, guiding small group discussion, managing class, and teaching individuals [1]. It was a survey study in a form of descriptive qualitative evaluative research design. The qualitative data were collected by using questionnaire and then were analyzed by interpreting and evaluating them objectively. The result of the data shows that teachers of international language center had good basic pedagogical competences. Among those eight pedagogical competences, the fourth skill of explaining was dominant. 19 undergraduate students chose "often" (number 4 at Likert scale) column. Implications and suggestions related to the research findings were made as part of an effort to improve the teaching practices in the language center.
\end{abstract}

Keywords: Teacher Education, Professional Development, Basic Pedagogical Competences, Tutorial Class

\section{Introduction}

Some universities apply compulsory additional classes in the form of English tutorials to their students [2] with the hope that these students will have sufficient provisions to be able to take the TOEFL (Teaching English as a Foreign Language) exam and obtain scores that meet graduation requirements. This also happened to several Islamic universities such as Universitas Islam Sultan Agung [3]. For this program, at least students must attend the additional courses for one semester. In these classes, students certainly find teachers or tutors who can help them learn and master English. 
However, there are also some teachers who have not been able to implement simple and easy-to-understand learning for students. This is because improving students' English skills cannot be separated from the role of the teachers or tutors who teach them. With the various strategies and motivations used, teachers can raise their enthusiasm in learning English [4],[5],[6].

The problem is that not all teachers have good basic pedagogical competences in the teaching process. Now in this case, researchers of the present study are eager to find out students' perception towards their teachers' pedagogical competences: whether the teachers who teach English tutorial classes at a particular religious university have good basic pedagogical competences in the teaching process or not then which of these basic pedagogical abilities is the most prominent and which ones are not and need to be improved.

\section{Basic Pedagogical Competences}

Basic pedagogical skill is a basic teaching skill which really needs to be mastered by teachers, including English language teachers because these skills are determinant to the success of teaching and learning. There are eight basic pedagogical competences according to Sumardiyani [1]. They are (1) asking question, (2) giving feedback, (3) making variation, (4) explaining, (5) opening and closing the lesson, (6) Guiding small group discussion, (7) managing class, and (8) teaching individuals.

The first skill is asking question. It is defined as a basic competence for teachers to asking question to students [1]. Teachers are supposed to exactly know how to ask questions to students wisely, to whom the questions are addressed, what kind of question to ask, and when the questions are given. Teachers, however, have their own types of questioning behaviours [7]. The types of questions can be display or "known questions" [8] and referential ones $[9,10]$ which can affect English classroom discourse [11] but surely those types should be able to make students think critically and dig deeper into the material being studied at that time. Questions can be designed to fulfill teachers' teaching purposes through attracting students' attention, stimulating specific cognitive processes, communicating information to the instructor and students via classroom response system-tabulated answer counts, and facilitating the articulation and confrontation of ideas [12]. Asking questions at certain times can also be an alternative way to manage the class effectively. The teacher can also make variations by providing opportunities for other students to answer questions from their classmates. This can foster a spirit of leadership and self-confidence for students who answer these questions.

The second skill, giving feedback, is absolutely the art of teaching. It is how teachers wisely give moving and supporting feedbacks to the students' works. Teachers as much as possible should avoid comments and input that can drop students, causing them to feel inferior and less confident. In terms of written feedback, teachers can provide themselves as good peer reviewers [13]. Feedback should also be clear about the point and not confuse students so they know what they should do. Feedback can be oral or written. If the feedback is verbal and is rather harsh, then it should not be in the presence of other students. In short, the feedback's role is actually to help students to achieve a high quality of performance consistently [14].

The third skill is to make variations of learning. Students tend to get bored easily when doing similar things repeatedly, especially for students at the basic education level. Therefore teachers need to rack their brains to be able to make variations in learning as creatively as possible. The teacher needs to look at students' conditions and situations while looking for strategies, techniques and approaches which are appropriate and effectively and efficiently 
applicable. There are so many techniques, strategies or even approaches can be employed. For instance, the teacher can use flipped classroom when teaching speaking [15] and vocabulary [16] or utilize Padlet in the form of blended learning [17]. Above, teachers should make sure that the class is in the form of self-organized learning environment [18].

The fourth skill is the ability to explain. The teacher must be able to provide explanations to students in ways and words that are simple and easy for students to understand. Complex explanations can make students confused and lazy to listen to the teacher's explanation. The teacher must ensure that his voice can be heard by students in the entire classroom When there are students sitting in the back asking questions, the teacher should not need to come closer to listen to the question. The teacher can stay ahead and ensure that questions raised by the student can be heard by other students. In doing so, the teacher is supposed to use clear, appropriate and acceptable classroom language [19].

The fifth skill is the ability to open and close learning. The teacher should open the lesson with motivating words. If the class is an English class, the teacher opens the class with English phrases that are always spoken (especially those related to formulaic expressions) at the beginning of learning so that students can easily remember and practice them correctly. Likewise with closing the class. If it is felt that students have understood and are fluent in practicing these expressions, the teacher can make variations in opening and closing the class so that the class becomes more enjoyable.

The sixth skill is guiding small group-discussions. When teachers teach in large classes, they need to form small groups. This small group is made to make a deeper discussion about a topic of study. It is better if the teacher determines the members in each group so that students can interact with other students because if they are left to choose their own group members, then they will tend to choose friends who are close to them only. During the discussion, the teacher can walk around and stop by each group: listen to what they are discussing and occasionally give questions and direction.

The seventh skill is the ability to manage classes. Classes here can mean students and classrooms. To manage students well, teachers need to know and understand each student's background and character. Students who like to play and run around while learning can be placed in front. When they keep making noise and disturbing other students, the teacher can ask him to come forward to explain the lesson or answer questions. Such students sometimes need reinforcement or some kind of praise. Therefore praise them when answering well: praise them properly and not too much. Meanwhile, teachers also need to have the ability to manage classrooms well. Student seats can be adjusted according to the number of students. Seats can be in the form of U-Shape or other according to class needs. If the class is in the form of a speaking class, students can sit in a circle so learning speaking can be more easily managed and students can better interact either with their teacher or classmates.

The last basic pedagogical skill is teaching individuals. The teacher must be able to teach individual student privately when necessary. Because teaching is also about how the teacher provides motivation to each student. Teaching is not only about transferring knowledge to students but also educating students to become real human beings, people who have affective and psychomotor skills. As a result, they will become complete humans, having not only hard skills but also soft skills, being students who have high empathic feelings and respect for others. 


\section{Method}

It was a survey research in the form of descriptive quantitative research design. The data were collected by using questionnaire and then were analyzed by interpreting and evaluating them objectively. Thirty students of English Tutorial Class at a private language institution in Central Java, Indonesia were the subjects of this research. In order to get the data, this research was conducted quantitatively using quantitative research method. Ten selected items of questionnaire related to the challenges and obstacles were distributed to 30 undergraduate students as the samples of the study. That samples were taken randomly by using purposive random sampling technique. The questionnaire was made in the format of Google Form so that the respondents could get and fill it easily online. The questionnaire was expected to reveal their perception about their tutors' pedagogical competence and their significance to them.

Table 1. Questionnaire of the Research

\begin{tabular}{|c|c|c|c|c|c|c|}
\hline No & Statements & Never & Seldom & Sometimes & Often & Always \\
\hline 1 & $\begin{array}{l}\text { Tutors check students' understanding by } \\
\text { asking material that has been or is being } \\
\text { discussed }\end{array}$ & & & & & \\
\hline 2 & $\begin{array}{l}\text { Tutors provide feedback in the form of praise } \\
\text { or positive comments on the results of work / } \\
\text { business / student questions }\end{array}$ & & & & & \\
\hline 3 & $\begin{array}{l}\text { Tutors make variations in learning activities } \\
\text { so students do not feel bored }\end{array}$ & & & & & \\
\hline 4 & $\begin{array}{l}\text { Tutors explain the subject matter in a } \\
\text { systematic planned order so that it can be } \\
\text { easily understood by students }\end{array}$ & & & & & \\
\hline 5 & $\begin{array}{l}\text { Tutors create a pleasant atmosphere when } \\
\text { opening lessons so students are ready to take } \\
\text { lessons }\end{array}$ & & & & & \\
\hline 6 & $\begin{array}{l}\text { Tutors close the lesson by ensuring that } \\
\text { students understand the material that has } \\
\text { been discussed }\end{array}$ & & & & & \\
\hline 7 & $\begin{array}{l}\text { Tutors are skilled in guiding small group } \\
\text { discussions }\end{array}$ & & & & & \\
\hline 8 & $\begin{array}{l}\text { Tutors are skilled in creating and maintaining } \\
\text { optimal classroom conditions so the teaching } \\
\text { and learning process runs effectively }\end{array}$ & & & & & \\
\hline 9 & $\begin{array}{l}\text { Tutors are skilled in guiding and encouraging } \\
\text { students to learn }\end{array}$ & & & & & \\
\hline 10 & $\begin{array}{l}\text { Tutors know each student's character } \\
\text { personally }\end{array}$ & & & & & \\
\hline
\end{tabular}

The questionnaire in Table 1 above is actually an adaptation the eight pedagogical competences based on Sumardiyani [1] including (1) asking question, (2) giving feedback, (3) making variation, (4) explaining, (5) opening and closing the lesson, (6) Guiding small group discussion, (7) managing class, and (8) teaching individuals. To reveal the students' perceptions of these 8 skills, 10 items of statement were made. One statement is used to measure one skill, but especially for skill 4 and 8 , they are measured by 2 statements each.

\section{Results and Discussion}


From the online questionnaire distributed to 30 students, it was then found that among the eight pedagogical competences, the explaining skill was the most practicing skill during teaching and learning process. This is evident as the data show that 5 respondents mentioned "always" and 19 respondents mentioned "often". If the number of responses on "often" and "always" are sum up, this statement has the highest frequency which can be interpreted as the most frequent skill practiced by tutor during the lesson. Unfortunately, most of teachers/tutors did not know the students personally. They did not really have close relationship with the students. It is because there are only four students claiming to agree that tutors know each student's character personally. It can be understood since students did not meet them regularly.

Table 2. The Result of the Study

\begin{tabular}{|c|c|c|c|c|c|c|}
\hline No & Statements & Never & Seldom & Sometimes & Often & Always \\
\hline 1 & $\begin{array}{l}\text { Tutors check students' understanding by } \\
\text { asking material that has been or is being } \\
\text { discussed }\end{array}$ & 0 & 2 & 10 & 14 & 4 \\
\hline 2 & $\begin{array}{l}\text { Tutors provide feedback in the form of } \\
\text { praise or positive comments on the } \\
\text { results of work / business / student } \\
\text { questions }\end{array}$ & 1 & 3 & 9 & 13 & 4 \\
\hline 3 & $\begin{array}{l}\text { Tutors make variations in learning } \\
\text { activities so students do not feel bored }\end{array}$ & 0 & 2 & 15 & 9 & 4 \\
\hline 4 & $\begin{array}{l}\text { Tutors explain the subject matter in a } \\
\text { systematic planned order so that it can } \\
\text { be easily understood by students }\end{array}$ & 0 & 0 & 6 & 19 & 5 \\
\hline 5 & $\begin{array}{l}\text { Tutors create a pleasant atmosphere } \\
\text { when opening lessons so students are } \\
\text { ready to take lessons }\end{array}$ & 0 & 1 & 14 & 11 & 4 \\
\hline 6 & $\begin{array}{l}\text { Tutors close the lesson by ensuring that } \\
\text { students understand the material that } \\
\text { has been discussed }\end{array}$ & 0 & 4 & 9 & 12 & 5 \\
\hline 7 & $\begin{array}{l}\text { Tutors are skilled in guiding small } \\
\text { group discussions }\end{array}$ & 1 & 2 & 11 & 15 & 1 \\
\hline 8 & $\begin{array}{l}\text { Tutors are skilled in creating and } \\
\text { maintaining optimal classroom } \\
\text { conditions so the teaching and learning } \\
\text { process runs effectively }\end{array}$ & 0 & 4 & 10 & 13 & 3 \\
\hline 9 & $\begin{array}{l}\text { Tutors are skilled in guiding and } \\
\text { encouraging students to learn }\end{array}$ & 0 & 1 & 11 & 12 & 6 \\
\hline 10 & $\begin{array}{l}\text { Tutors know each student's character } \\
\text { personally }\end{array}$ & 0 & 9 & 14 & 4 & 3 \\
\hline
\end{tabular}

From Table 2, it can be concluded that most tutors often check students' understanding by asking material that has been or is being discussed. None of them never did it. It is almost the same as the second item of statement in which tutors also often provide feedback in the form of praise or positive comments on the results of work / business / student questions. The difference is that there is still tutor who did not provide feedback to students. Most of tutors sometimes make variations in learning activities so students do not feel bored and they also sometimes create a pleasant atmosphere when opening lessons so students are ready to take lessons. 
Table 2 also shows that tutors often close the lesson by ensuring that students understand the material that has been discussed, are skilled in guiding small group discussions, creating and maintaining optimal classroom conditions so the teaching and learning process runs effectively, and guiding and encouraging students to learn.

\section{Conclusion}

Some conclusions can be drawn here. Most of the teachers have good cognitive abilities towards materials. However, they lack of interpersonal skill. Though it seems to be small and trivial, this skill much affects the success of learning. Establishing good relationships with students is one part of the strategy in making learning successful. Students who feel close to their teacher will try their best to understand the subject matter in the hope that the teacher will be proud of him.

Indeed, to be able to make the eight skills ingrained in the soul of a teacher, he must train and continue practicing them. Of course it takes a lot of effort to develop creative and innovative ways of teaching. These efforts can be in the form of independent learning from a variety of literature and training or workshops on teaching, but most importantly is practice. The teacher may also patiently conduct various experiments, trials and errors, action research, so that learning can be delivered in various enjoyable ways and develops the best potentials of the students.

\section{References}

[1] Sumardiyani, L.: Dasar komunikasi dan keterampilan dasar mengajar. Semarang: Kopertis Wilayah VI Jawa Tengah, Kementerian Riset Teknologi dan Pendidikan Tinggi (2016)

[2] Wu, E., Lin, W. C., \& Yang, S. C.: An experimental study of cyber face-to-face vs. cyber text-based English tutorial programs for low-achieving university students. Computers \& Education, 63, 52-61. https://doi.org/10.1016/j.compedu.2012.11.018 (2013)

[3] http://cilad.unissula.ac.id/tutorial-bahasa-inggris/ retrieved on 24 September 2017

[4] Moskovsky, C., Alrabai, F., Paolini, S., \& Ratcheva, S.: The effects of teachers' motivational strategies on learners' motivation: A controlled investigation of second language acquisition. Language learning, 63(1), 34-62. https://doi.org/10.1111/j.14679922.2012.00717.x (2013)

[5] Vibulphol, J.: Students' Motivation and Learning and Teachers' Motivational Strategies in English Classrooms in Thailand. English Language Teaching, 9(4), 64-75. http://dx.doi.org/10.5539/elt.v9n4p64 (2016)

[6] Anwar, C., \& Nugroho, K. Y.: Students' motivations toward choosing English education. Indonesian EFL Journal, 4(1), 57-64. DOI: 10.25134/ieflj.v4i1.799. (2018)

[7] Hargie, O. D.: The importance of teacher questions in the classroom. Educational Research, 20(2), 99-102 (1978)

[8] Mehan, H.: 'What time is it, Denise?": Asking known information questions in classroom discourse. Theory into practice, 18(4), 285-294 (1979)

[9] Long, M.H., \& Sato, C.J.: Classroom foreigner talk discourse: Forms and functions of teachers' questions. In H.W. Seliger \& M.H. Long (Eds.), Classroom oriented research in second language acquisition (pp. 268-285). Rowley, MA: Newbury House (1983) 
[10] Kearsley, G.P.: Questions and question-asking in verbal discourse: A cross-disciplinary review. Journal of Psycholinguistic Research, 5, 355- 375 (1976)

[11] Brock, C. A.: The effects of referential questions on ESL classroom discourse. TESOL quarterly, 20(1), 47-59 (1986)

[12] Beatty, I. D., Gerace, W. J., Leonard, W. J., \& Dufresne, R. J.: Designing effective questions for classroom response system teaching. American journal of physics, 74(1), 31-39 (2006)

[13] Berggren, J.: Learning from giving feedback: A study of secondary-level students. ELT journal, 69(1), 58-70. (2015)

[14] Thomas, J. D., \& Arnold, R. M.: Giving feedback. Journal of palliative medicine, 14(2), 233-239. (2011)

[15] Anwar, C., \& Pratama, A.:Flipped classroom in teaching speaking to young learners. In Proceeding of The 63rd TEFLIN International Conference" Creativity and Innovation in Language Materials Development and Language Teaching Methodology (Vol. 1, pp. 285-289). (2016)

[16] Anwar, C.: Flipped classroom in teaching vocabulary to EFL young learners. In Conference Proceedings of The 2nd International Conference 2017 on Teaching English for Young Learners (TEYLIN): Indigenous norms to the coming age of one Asia (pp. 109-115). (2017)

[17] Anwar, C., Nugroho, K. Y., \& Nurhamidah, I.: Students' Perception at the Use of Padlet in Linguistics Class. NOTION: Journal of Linguistics, Literature, and Culture, 1(1), 35-41. (2019)

[18] Anis, M., \& Anwar, C. (2020). Self-organized learning environment teaching strategy for ELT in Merdeka Belajar concept for high school students in Indonesia. JEES (Journal of English Educators Society), 5(2), 199-204. https://doi.org/10.21070/jees.v5i2.869

[19] Dewi, I., \& Anwar, C.: Senior High School EFL Teacher and Students' Use of Classroom Language. JEES (Journal of English Educators Society), 3(1), 105-118. doi:http://doi.org/10.21070/jees.v3i1.1336 (2018). 